\title{
THE
}

\section{Toward Optimizing Global Learning Opportunities for US Physical Therapy Students: A Description of Current Practices and Initial Recommendations}

Jennifer Audette

University of Rhode Island, jaudette@uri.edu

Cathy Peterson

Lana Svien

Follow this and additional works at: https://digitalcommons.uri.edu/pt_facpubs

The University of Rhode Island Faculty have made this article openly available. Please let us know how Open Access to this research benefits you.

This is a pre-publication author manuscript of the final, published article.

Terms of Use

This article is made available under the terms and conditions applicable towards Open Access Policy Articles, as set forth in our Terms of Use.

\section{Citation/Publisher Attribution}

Audette, J., Peterson, C., \& Svien, L. (2018). Toward Optimizing Global Learning Opportunities for US Physical Therapy Students: A Description of Current Practices and Initial Recommendations. Journal of Physical Therapy Education, 32(1), 77-86. doi:10.1097/JTE.0000000000000027

Available at: http://dx.doi.org/10.1097/JTE.0000000000000027 


\begin{abstract}
Purpose: To examine and describe the structure, curricular objectives, and outcome measurement practices of faculty developing and providing international opportunities in physical therapy (PT) education programs, and to provide guidance and initial recommendations for faculty.
\end{abstract}

Background: Physical therapy educational programs are adding international opportunities as a way to address the increasingly global nature of the profession. Guidelines to enhance practice, optimize the experience, and provide structure for managing risk are warranted.

Methods: A researcher-developed survey was distributed to 216 PT education programs and professional listservs. Respondents from fifty-six programs (26\%) returned the survey. Data were analyzed descriptively.

Results: The majority of respondents cited global understanding as critical to the PT profession, and the reason for involving students in global learning opportunities. Knowledge of host site, sustainability, and potential strength of partnership were cited as the most important factors when choosing an international community partner. Risk management efforts included supplemental insurance, availability of emergency contact information, safe transportation and housing plans, and plans for adverse occurrences.

Conclusion: This study supplements previous literature in designing international student experiences. Activities addressing clear purposes and expected outcomes for all participants, including the community partner, and the university-community partnership prior to, during, and after the experience are essential.

\title{
Introduction
}


Global experiences (service-learning and others) are increasingly popular throughout higher education ${ }^{1}$, and many physical therapy (PT) educational programs are adding international experiences and opportunities to their curricula. ${ }^{2-4}$ Development of these experiences aligns with the increasingly global nature of our profession. ${ }^{5}$ Globalization is influencing healthcare, and physical therapists are likely to encounter marked diversity in any setting in which they practice. Indeed, the $21^{\text {st }}$ century has seen the profession of PT taking a more global stance and positioning itself for enhanced international awareness and collaboration. ${ }^{5,6}$ Therefore, providing opportunities for PT students to experience diversity and increase their cultural competence is critical. One way to address these issues in academic programs is to offer international experiences as part of curricula or encourage participation in elective opportunities organized by PT faculty. International opportunities may be one way to meet accreditation standards related to cultural competence ${ }^{7}$ but educators have also identified them as being valuable for enhancing other aspects of the educational experiences of students. ${ }^{8-16}$ These international experiences may help to develop skills and attributes that enhance students' preparation for practice in this culturally diverse and global health arena.

Despite the potential benefits, the proliferation of programs raises ethical concerns ${ }^{17-21}$ and increases the potential for occurrence of adverse incidents. ${ }^{22,23}$ Managing the risk of safety and ethical incidents can take many forms. In addition to more typical risk management practices undertaken by faculty and often mandated by university risk management or study abroad offices (such as following legal and procedural mandates, purchasing extra insurance coverage, and emergency preparedness activities), faculty can further reduce the risk of unethical and/or unsafe situations by developing experiences that are structured and well prepared for. This structure and 
preparation might include in depth consideration of the purpose and expected outcomes of the program, student and faculty preparation and participation, the quality of international partnerships, and the interaction with the people served. Therefore, thoughtful and diligent planning and preparation are critical to create experiences that meet stated objectives, while being meaningful, ethical, safe, and sustainable.

\section{Review of Literature}

The following review of the literature includes exploration of the evidence that exists related to faculty practice, challenges to ethical and safe program development, and outcome measurement for international opportunities for students. The literature informed the development of the methodology and the interpretation of the resultant data for this study.

Faculty Practice

Apart from anecdotal information suggesting that many PT programs are offering international options, little evidence is available regarding who is developing them, why and how they are being developed, how many there are, how many students are participating, or where they are occurring. One study ${ }^{2}$ began to describe the demographics of faculty who lead international student opportunities. Aside from that study little has been published about the demographics and experience of faculty who plan and lead international student opportunities.

There is no aggregate data available about how locations are chosen, length, locations, type and number of participants, costs, or funding for international offerings. Further, other than case specific descriptions, no studies have explored the programmatic reasons for offering international opportunities, the objectives of those opportunities, the reasons faculty get involved, or levels of administrative support. 
Understanding the motivations for why PT faculty are involved in developing and participating in international student opportunities is important because the reasons may have a major influence on how experiences are conceptualized and brought to fruition. Faculty may not be aware of, or be guided by, existing literature that could support and inform international student opportunity practices and objectives. There is a paucity of literature regarding why faculty become involved in international opportunities. ${ }^{24-28}$ However, in the service-learning related literature, Hammond ${ }^{26}$ suggests that three predominant categories of faculty motivators exist: personal, co-curricular, and curricular. Personal motivators include past involvement in service activities, affinity for service and an interest in helping those in need, endorsement of social change, and a desire to work with students outside the classroom. Faculty co-curricular motivators include beliefs that such activities will promote civic involvement, moral character development, and improved multicultural understanding in students. Curricular motivators include effective presentation of content material, encouragement of self-directed learning, professional training, and experiential application of content. Faculty have also reported servicelearning helps to develop global citizenship and an understanding of common good, justice, equity, and fairness in students. ${ }^{26}$ Some authors have found faculty to be motivated to use service-learning because it: 1) creates opportunities to shape the civic and moral dispositions of students, 2) serves as a positive model for teaching and learning, 3) provides an opportunity for students' expression of personal identity, 4) can be an expression of institutional mission and values, and 5) fosters valuable community partnerships. ${ }^{25-28}$ Data on faculty outcomes have yet to be published.

Challenges and Preparation 
In medicine, best practice guidelines for global health training experiences have been proposed which include ideas from the Working Group on Ethics Guideline for Global Health Training (WEIGHT) ${ }^{29}$ In their exploration of international clinical education for PT students, Pechak and Black ${ }^{30}$ proposed guidelines for structuring, carrying out, and evaluating clinical education abroad. However, other than case specific studies where some aspects of participant preparation are described, there is no literature that explores how students and other participants should be prepared for PT international opportunities.

Inherent in the preparation for international opportunities there must be an appreciation for - and attention to - potential ethical and safety challenges. Ethical violations such as lack of sustainability, lack of clear educational objectives, failure to address local community needs and reciprocity, and inadequate student supervision, and inadequate implementation of risk management efforts have been found. ${ }^{17-21,29-32}$ It has been reported that this is most often due to inadequate preparation about the ethical and safety dilemmas participants might encounter. The literature suggests that intensive pre-departure training and reflection during and after the experience are measures that can be taken to minimize ethical and safety risks. ${ }^{31-36}$ There are no published studies about mitigating challenges and risk related specifically to taking PT students abroad.

\section{Outcome Measurement}

Several studies have stated the importance of measuring stakeholder outcomes ${ }^{13-}$ 15,20,29,30,37 and, again, others have discussed how individual programs measure various outcomes. ${ }^{20,24,37-43}$ Authors agree there is value in assessing and measuring student outcomes such as attitudes and critical thinking ability, ${ }^{24,41,42}$ global citizenship, ${ }^{43,44}$ cultural competence, ${ }^{45-}$ 
${ }^{49}$ clinical skills, ${ }^{50-52}$ and professionalism. ${ }^{53}$ Also, it is generally agreed that opportunities for reflection can enhance student outcomes. ${ }^{54,55}$ However, there is no consensus about what should be measured, how outcomes ought to be measured, or what tools should be used. Studies have indicated outcomes related to various stakeholders (PT programs, faculty leaders, students, host sites, and those served in the host sites, etc.) should be considered, yet no agreed upon tools have been identified. Most programs that do measure outcomes have done so by utilizing homegrown tools or tools that have been developed by those in other disciplines.

Because the inclusion of international opportunities in PT curricula is a relatively new and rapidly growing educational endeavor, it is vitally important to begin to establish and utilize standard expectations and guidelines. Research providing rationale that supports, justifies, and legitimizes the time and cost required to undertake international opportunities is necessary. Further, studies that provide information that can help faculty develop programs where the experience is optimized and risk is minimized are needed. The purpose of this study is to examine and describe the structure, curricular objectives, and outcome measurement practices of faculty developing and providing international opportunities in physical therapy education programs, and to provide guidance and initial recommendations for faculty.

\section{Subjects}

Faculty from 56 PT programs across the United States (US) who have developed, or are in the process of developing, international opportunities for students participated in the study. Participants were recruited via direct emails to each of the 216 PT education programs listed on the Accredited PT Education Programs page of the American Physical Therapy Association (APTA) website. A consent document was provided on the first page of the survey and consent 
was assumed when participants completed the survey. This study was approved by the University of Rhode Island Institutional Review Board.

\section{Methods}

$\underline{\text { Instrument }}$

From a review of the literature, it was discovered that an existing tool to measure the items focused on in this study was not available. A researcher-developed tool was created following a thorough review of the literature and incorporation of key themes from the literature. Items were developed to gather a variety of data related to various key aspects of developing and leading international experiences that are beneficial and safe. Prior to dissemination, a panel of five experts with substantive experience in survey design and research reviewed the survey to assess clarity and face validity. Revisions and modifications were made in response to their feedback.

The survey was comprised of 50 open-ended, multiple choice, multiple response, ranking, and multiple item Likert response questions. The survey items were organized into six sections. Section 1 included 12 standard demographic queries: including sex, educational background, years of experience, area of expertise, and experience in planning and leading international student opportunities. Section 2 asked for specific information about international offerings. Respondents were asked to answer 15 opportunity specific questions. The questions were related to length of opportunity, number of opportunities offered to students annually, number of student participants annually, costs and funding for students and faculty, whether or not trips are interdisciplinary, and factors influencing choice of location. Each respondent could provide information for up to 5 different opportunities. Section 3 included 6 questions related to 
the programmatic reasons for offering international opportunities, the objectives of those opportunities, the reasons faculty get involved, and whether or not programs are supported by university administration. Information about participant selection and preparation was requested in section 4. This included 6 questions related to student participants, faculty/leader participants, and any other participants. Risk management efforts and faculty concerns were explored with 6 questions in section 5. Items related to emergencies, travel insurance, housing and transportation were included. In this section respondents were also asked to report how often they worry about a variety of things when planning and leading international opportunities. Lastly, information about outcome measurement was requested with 5 questions in section 6 . This included outcomes related to students, faculty/leaders, host sights, and university - community partnerships.

$\underline{\text { Procedures }}$

A letter of introduction, which included a link to the survey, was emailed to each of the 216 PT programs in the US. It was requested that the SurveyMonkey ${ }^{\mathrm{TM}}$ link be passed on to the most appropriate person. In addition, two professional listservs were utilized to seek participation also via the SurveyMonkey ${ }^{\mathrm{TM}}$ link. This sample was a purposeful convenience sample. ${ }^{56}$ Accessing subjects via listservs is not a probabilistic sampling technique, but utilizing the listservs provided a mechanism to reach a geographically diverse subject pool with specific interests in an economical, timely, anonymous, and efficient manner. Lastly, snowball sampling was utilized; subjects were asked to share the survey link with other interested PT faculty who may not have been included in direct emails or the listservs. An informed consent statement was provided on the first page of the on-line survey. 
$\underline{\text { Data Analysis }}$

Descriptive statistics (frequency and percentage) were calculated for the study variables: mean and standard deviation were calculated as indicated using SPSS24. ${ }^{57}$

\section{Results}

Because not all participants answered all questions, the number of respondents is reported for each item. Moreover, some programs had multiple sites, therefore the number of programs varies from other sample size numbers.

Faculty Demographics and Experience

The majority of the faculty respondents leading international opportunities are female, and have been in academia for nearly 15 years. Nearly $43 \%$ had earned PhDs in one of the following areas: education (3), rehabilitation science (2), doctor of health sciences (2), neuroscience (2), biomedical engineering (2), kinesiology, PT with public health concentration, anatomy and cell biology, interdisciplinary sciences, biomechanics, exercise physiology, educational psychology, experimental psychology, health/physiology, health services research, doctor of business administration, and pathokinesiology ( 1 of each).

When asked what the total number of international experiences they had planned or developed in total, the 54 participants who responded reported a range from 1-16, with a mean of $3.87(\mathrm{sd}=3.48)$. The average number of trips each respondent has participated in overall, ranged from 0-25 trips with a mean of 6.65 (sd 6.22). Each respondent generally participated in 1 per year. Respondents reported that their programs offer an average of 2.38 international opportunities to students each year, and an average of about 12 students participate annually. Table 1 provides a summary of demographic information. 


\section{Faculty and Program Objectives}

The majority of faculty identified: personal; co-curricular; and support for the institutional mission and values as reasons for being involved in developing and leading international opportunities for students (Table 2). A wide variety of educational reasons for offering international opportunities for students were reported (Table 3), however, the most frequently reported reason was the importance of global understanding. When asked to rank (1 most important, 7 least important) program objectives and outcomes, the top 2 reasons for providing international experiences for students were "Provide exposure to a diverse population / setting" and "Provide a life-changing experience for students."

\section{Costs, Funding, and Curricular Options}

In addition to airfare, the average daily cost for both faculty and students was estimated at between $\$ 51$ and $\$ 75$ per day. Faculty respondents reported their expenses were paid in a variety of ways. Although multiple responses were allowed, $44 \%$ reported their expenses were covered with departmental funds, $31 \%$ reporting self-funding, $24 \%$ reported that some funding came from student fees, $11 \%$ reported getting money from a Dean's fund, and $9 \%$ getting some funding from their global studies office. Additionally, faculty reported combinations of grants, scholarships, personal funding, and/or donations from friends or churches. With respect to student funding sources, again, multiple responses were allowed and reportedly, students pay their own expenses (94\%), secure internal grant funding (26\%), receive departmental funds (21\%), and receive external grant funding (13\%).

In general, international opportunities that were identified as being credit-bearing $(80 \%)$ also had a syllabus and were graded. Of credit-bearing courses, the majority were longer in 
duration (two weeks or more) and considered to be non-elective. About $70 \%$ of the experiences were reported as "not- required" regardless of their length or credit-bearing status. Some opportunities could be taken for credit or not, depending on student needs. For trips where faculty traveled with students, the majority of study participants reporting a faculty:student ratio of $1: 5$ (range $1: 2$ to $1: 15)$.

\section{$\underline{\text { Locations and Partners }}$}

A wide variety of locations and reasons for choosing destination and host site were reported (Table 4). When asked what factors influence choice of destination (multiple responses allowed) faculty overwhelmingly reported that knowledge of host site, likelihood of sustainability, and potential strength of partnership were most important. Additional factors included: the language spoken (45\%), the clinical opportunities available (35\%), the types of clients served (33\%), and the cost (30\%). Whereas factors such as availability of a variety of local experiences for students (23\%), diversity of the culture (18\%), opportunity for servicelearning $(15 \%)$, location $(10 \%)$, and climate $(8 \%)$ were reported less frequently. Further, when asked about any other factors, participants reported such things as; the opportunity for immersion in a different socio-cultural setting, faculty interest, the needs of the international partner, availability of translators, physical beauty, and access to fun activities on days off.

Participants were asked how important various factors were when considering and choosing a community/host partner. Of note, the presence of a local physical therapist was seen as "very important" or "important" by only $36 \%(\mathrm{n}=13)$ and $24 \%(\mathrm{n}=9)$ ranked this "unimportant" or "very unimportant." 
In terms of whether or not international opportunities were interprofessional, $65 \%$ reported that their opportunities were interdisciplinary and 35\% reported that they were not. For those programs that reporting having interprofessional involvement, the majority were collaborating with students in occupational therapy (17), nursing (11), and medical (10) programs. Several participants who do not currently offer interprofessional opportunities reported that they plan to make their opportunities interprofessional in the future.

\section{$\underline{\text { Participant Selection and Preparation }}$}

Students were selected for participation in international programs in a variety of ways. Multiple responses were allowed and of the 38 participants who responded to this item, 63.2\% (n $=24)$ reported having an application process and $60.5 \%(n=23)$ took professional behaviors into account. Some considered grade point average $(n=18 ; 31.6 \%)$ and some reported that any student who wants to go can $(n=11 ; 29.0 \%)$. Few require medical screening $(n=5 ; 13.2 \%)$ and only 1 program reported requiring previous travel experience or language proficiency.

The programs that reported having faculty leaders $(n=28 ; 50 \%)$ provided the following information (multiple responses were allowed); $11(31.4 \%)$ reported that anyone who is interested can lead a trip; 8 (22.9\%) said leaders must have previous experience taking students abroad; 4 (14.3\%) reported that leaders must have previous personal international travel experience; and 4 (14.3\%) said that they choose a colleague who they felt would be good. Two programs $(7.2 \%)$ reported using former students as leaders and one program reported having an application process for leaders. In addition, programs tended to allow other types of participants. These included professional colleagues, former students, faculty friends and spouses, and 
students' spouses. Still, 13 of the programs reported that they do not allow any participants other than faculty and students.

When asked what sort of information was provided to all participants prior to a trip, the 36 respondents identified topics that fall into three main categories (Table 5). The majority (65\%-75\%) discussed these issues with all participants and did not differentiate between information shared with students and information shared with faculty. Items that were reported as not being addressed at all by one or more respondents include: leader roles and responsibilities, program objectives, learning objectives, information about local medical providers/hospitals, inquiring about and responding to traveler's concerns, communication - on site, home, with participants, immunization and Center for Disease Control recommendations, outline of explicit rules and expected behaviors, notions about culture, money / currency, illness, packing list, and clinical issues. Eight programs responded that they do not address means for dismissal with either students or faculty.

When asked more specifically about student preparation before the experience, two categories of preparation are evident from the multiple responses of 36 study participants. The first was information and activities to prepare the student for the experience and enrich the experience such as: discussion of global health issues $(33,83.3 \%)$, required readings (19, $52.8 \%)$, team building $(18,50.0 \%)$, and personal goal development $(11,30.6 \%)$. The second category was practical issues such as: fundraising $(22,61.1 \%)$, involvement in logistics planning $(18,50.0 \%)$, collection of items to bring and donate $(17,47.22 \%)$, contact with host site $(8$, $22.2 \%)$, and collection of money to bring and donate $(4,11.1 \%)$.

\section{$\underline{\text { Risk Management }}$}


Preparing for international settings appeared to be multifaceted. Regarding insurance, the majority (74\%) required travelers to get special travel medical insurance, and the majority (45.7\%) do not require evacuation insurance. Of the respondents, $64 \%$ indicated that they do not register with the US Embassy. Table 6 indicates the various information and items that leaders carry with them.

The majority of respondents $(80 \%)$ reported that they used private transportation or rental vehicles hired or provided specifically for the group, with $44 \%$ reporting use of public transportation. Fifty percent $(50 \%)$ of respondents reported spending a majority of nights in housing provided by the community partner / host. Other options, though lesser utilized, included hotel, home stay arrangements, and hostels.

Participants were asked what they worry about when planning and participating in international opportunities. Although the way in which data were collected makes it difficult to make definitive statements about the results, some trends indicate that the majority of leaders worry most about minor or major illness or injury of group members and transportation accidents. Most respondents reported "never" or "seldom" worrying about group members drinking too much, getting lost, experiencing mental health issues, being arrested, being bitten by animals or harmful insects, having swimming accidents, experiencing violence, harassment, or sexual assault from other group members or local people, witnessing violence, being kidnapped, or dying. Further, most "never" or "seldom" worried about terrorist threats or natural disasters.

\section{$\underline{\text { Outcome Assessment }}$}

Student. With regard to using formal or standardized outcome measures to assess students, 55\% $(\mathrm{n}=21)$ responded affirmatively. Examples given included: reflective writing, 
report of activities, oral presentation, evaluation of attitudes and behaviors, clinical evaluation by supervisor, goals, practical examination, written papers, facilitator and barrier identification, program improvement analysis, grading rubrics, standardized clinical assessment tools, publications, locally developed learning objectives, and group projects to assess student outcomes.

Host site. Nearly $80 \%$ of participants reported that they do not use any formal or standardized outcome measures to assess their host sites. The small percentage of those who do stated that they utilize: student evaluations of the site, "outcome analysis", "the host site staff fills out a survey that consists of Likert and open-ended questions rating our program and providing direction for future programming”, “evaluations available from professional organization", assessment of clinicians involved with students, and a satisfaction survey. Two participants reported that they plan to initiate site assessment in the near future.

Partnership. When asked if they use any formal or standardized outcome measures to assess university-community partnerships, $92 \%$ said they do not. One respondent said they use "many" but did not elaborate and 2 stated they were working on tools to be used in the future.

Faculty. Fewer than a fourth of respondents indicated use of formal or standardized outcome measures to assess faculty leaders. Examples included: course evaluations, student evaluations, submission of a vita, and peer review.

\section{Discussion}

The purpose of this study was to examine current practices related to developing and providing international student opportunities, discuss strategies to manage risk and promote optimal experiences, and to propose initial recommendations. The results of this study add to 
what is known and lead to some initial guidelines that should be considered by PT faculty developing international programs. The guidelines based on the findings from this study support and reiterate those previously identified in the literature. ${ }^{29,30}$

Although the data do not provide exact information about how many (or what percentage) of all 216 accredited programs are actually offering international opportunities, it can be assumed that the 56 respondents represent a relatively high number of those programs that are - assuming that all are not. In and of itself, this number is important. Strikingly, $26 \%$ of the programs nationwide responded that they are undertaking international efforts. This response allows some important conclusions to be made. Further, recruitment mechanisms allowed the researchers to reach a geographically diverse subject pool with specific interests in an economical, timely, anonymous, and efficient manner.

Given that international experiences are increasingly popular and align well with student interest and the increasingly global nature of our profession, ${ }^{5}$ it is important that they are of high quality. This includes addressing risk management issues and ethical concerns while creating opportunities where participants are well-prepared with a clear purpose, clear objectives, and use of outcome measures.

\section{Faculty Demographics and Experience}

This study adds to what is known about PT faculty who develop and lead international opportunities for students. As was found in previous research ${ }^{2}$, it appears that most faculty planning and leading international opportunities have quite a bit of seniority and experience in academia. This can be advantageous in several ways. Perhaps these faculty have a level of clout that allows them to initiate international programs and capitalize on existing professional 
international relationships. It is likely they have strong curricular knowledge and experience developing student learning activities and objectives. The reasons faculty are involved also seem to support past literature. ${ }^{40,25-28,58}$ The vast majority reported that they are involved for reasons that are "personal" or "co-curricular." It would be interesting to explore how/if these efforts are weighted in promotion and tenure processes. RECOMMENDATION \#1: Senior faculty with experience leading international opportunities with students should mentor faculty to become future leaders of international opportunities (Table 7).

\section{Purposes and Objectives}

Consistent with the literature, most respondents ranked items such as; enhancing global understanding, providing students with exposure to a diverse population/setting, and providing a life-changing experience for students as most important. This corroborates the "personal" and "co-curricular" reasons for faculty involvement and might create a conflict for those trying to develop and justify programs that meet professional, curricular, and/or accreditation ${ }^{7}$ expectations. RECOMMENDATION \#2: Faculty should consider making objectives explicit and structuring the experience to: a) enhance participants' global understanding; b) expose participants to diverse populations and settings; and c) provide a life-changing experience for participants.

\section{International Offerings and Partnerships}

International opportunities are expensive for students, faculty, and programs. Although this study provides some preliminary information, further research is needed to explore cost benefit ratios. Better outcome measures and data are necessary for that to happen. This will allow programs to make important curricular decisions when incorporating international opportunities. 
Destinations and host sites are chosen for a wide variety of reasons, however, faculty overwhelmingly reported that knowledge of host site, host site mission, and the likelihood of a sustainable, strong partnership were felt to be among the most important factors. This underpins the thought and care with which partnerships must be undertaken. Logistical factors such as location, climate, and the presence of a local physical therapist were seen as less important.

The occurrence of interprofessional international opportunities is on the rise. Program developers should consider the value of interprofessional opportunities and carefully develop the related objectives and expected outcomes. Perhaps the data indicate that careful thought should be given to decisions related to which disciplines will participate and how learning objectives relevant for all - will/can be accomplished.

While most programs seem to be occurring in Mexico, Central, and South America, the data indicate that study participants have international programs all over the world. No dynamic, up-to-date professional database, clearinghouse, or directory currently exists. Such an entity might provide educators with this, and other important information, that could facilitate sharing of resources, collaboration, improved sustainability, and research opportunities.

RECOMMENDATION \#3: An entity such as the APTA's Section on Education, Section on Health, Policy, and Administration The Catalyst, Global Health Special Interest Group, or other should consider creating and maintaining a dynamic and up-to-date international opportunities resource website.

\section{$\underline{\text { Participant Selection and Preparation }}$}

While there is no consensus in the data about how leaders are chosen, students are selected for participation in international programs in a variety of ways. An application process 
seems to be common, but professional behaviors seem to be considered more often than grade point average.

Reportedly, a wide variety of information is provided to participants from three main categories; information to optimize the experience, logistics information, and risk management information. Interestingly, several programs reported that they do not address means for dismissal with either students or faculty. The data from this study seems to indicate that faculty leaders are not provided with all of the same information that students are given - even in areas that would be important to them. The depth with which each topic is covered was not explored in this study. Further research is warranted that would better describe the importance placed on each topic and the specific nature of the information shared.

Preparatory activities for students often include discussion and or course work relates to global health, required reading, group team building, personal goal development, fundraising and logistics planning. Nearly half of respondents collect donation materials to bring and distribute and many fewer collect monetary donations. This should be explored further since there are those who feel that sometimes more harm than good is done when people who mean well arrive at partner sights with unnecessary and unwanted donation items. ${ }^{59,60}$

\section{$\underline{\text { Risk Management }}$}

This is the first study to collect data related to faculty concerns and risk management activities undertaken by PT faculty when organizing international student experiences. A general consensus of what should be done would be beneficial to program leaders.

Most programs require some sort of supplemental insurance. Notably, very few programs let the US embassy know they will be visiting a foreign country. Depending on the nature of the 
trip and presence of a faculty leader, student and faculty emergency contact information, copies of passports, first aid, and emergency funds are carried. The variability in responses to housing and transportation questions is likely due to the diversity of locations, availability, and the nature of the host sight.

This study provides preliminary information about what faculty leaders worry about which can be compared to the information reported by a company that provides insurance for university students travelling abroad. ${ }^{61}$ This company reports that most trip organizers, students, and parents tend to worry about big problems like death, kidnapping, natural disasters, civil/political unrest, and terrorism. Whereas the things that should be worried about, because they are much more common (sexual/physical assault or harassment from a group member or other, mental health issues, serious illness/injury, arrest/questioning by local police, slips and falls, swimming mishaps, transportation related safety, getting lost, minor injury, and animal and insect bites), are given less attention..$^{22,23,61}$ Further exploration of what worries leaders is warranted to better understand if what they actually worry about is what they should be worrying about. This is important since worry is likely an indicator of what is considered, attended to, discussed with the group prior to experiences, and planned for in ways that minimize risk. Of course, this information should be put into the context of the location being traveled to, since location specific risks can vary widely. Risk management efforts protect faculty, students, the host site, and the University. Faculty should consider what sorts of things leaders and participants (and/or their parents) worry about going wrong, and weigh those with what should be worried about and planned for. RECOMMENDATION \#4: When preparing for an international opportunity the university's office of risk management should be consulted. 


\section{$\underline{\text { Outcome Measurement }}$}

Many of the respondents reported having syllabi for their international experiences, and three expected student outcomes stood out from the rest: 1) improved understanding of global health issues; 2) higher levels of cultural sensitivity and competence; and 3) higher levels of cross-cultural understanding. As a means to those ends, faculty generally require frequent and regular updates and feedback, daily debriefing and/or reflection, and journaling.

Educational programs need to get better at measuring the outcomes of international student experiences. ${ }^{2,10,13-15,19,20,30,57,62}$ The data show that only a few programs are doing this well. For example, are they measuring using evidence based, accepted tools, measuring the outcomes of all stakeholders, and utilizing outcome data. Many other respondents reported that they are measuring outcomes, however, their responses indicate otherwise. No agreed upon tools were identified. This is perhaps due to the fact that goals and objectives differ from program to program. Having at least some agreed upon goals and objectives, and assessment tools would be helpful. Collaborative research across universities would allow for richer aggregated data to identify goals, objectives and outcome measurement tools that could be used universally. RECOMMENDATION \#5: Determine objective and measurable outcomes agreed upon in advance by each stakeholder (host, student, faculty) and following the experience, complete an assessment examining a priori outcomes, whether cultural competence ${ }^{63-67}$, professionalism $^{65}$, interprofessional practice ${ }^{68,69}$, or civic learning. ${ }^{67}$

\section{Limitations and Future Research}

Although convenience samples are often used, they may not be representative of the whole population, and as such might be biased toward those who chose to participate and should 
be considered in that context. The instrument was developed by the researchers and was not validated beyond the panel of 5 experts. Moreover, the tool was lengthy and could have resulted in participant fatigue. Additionally, it may have been helpful to more clearly operationalize definitions (long-term and short term experiences, and clinical education for example).

In light of the fact that this is a preliminary study, it can be used as a steppingstone to prompt future research that might include more rigorous exploration of subtopics. Although beyond the scope of this study, analysis of the affects of host location with further analysis of the data by country would be beneficial since objectives and safety issues would likely be different in developed versus developing locations. Studies exploring appropriate goals and objectives and learning activities would also be beneficial. Insight about creative and useful ways to measure outcomes for all stakeholders is needed. And additional research is warranted to explore the costbenefit ratio of international opportunities for students, faculty, universities, and hosts.

\section{Conclusion}

The purpose of this study was to begin to describe faculty practice related to the development, curricular objectives, and outcome measurement practices of faculty developing and providing international opportunities in physical therapy education programs, and to provide guidance and initial recommendations for faculty. Educators involved in taking or sending students abroad should consider the recommendations provided in Table 8 . In order to remain salient, these guidelines will need to evolve with continued findings from research and reflection. Although the results of this study are most applicable to PT education, they can also provide information that may be useful to other health disciplines initiating international student opportunities. 


\section{References}

1. 2015 Open Doors Report on International Educational Exchange. Institute of International Education. Available at http://www.iie.org/en/Research-and-Publications/OpenDoors\#.V5Zy2q7ey0c. Accessed July 1, 2016.

2. Audette JG, Roush SE. Educational perspectives and teaching styles of faculty who lead international service-learning experiences. J Phys Ther Educ. 2013;27(2):65-73.

3. Pechak CM, Thompson M. A conceptual model for international service-learning and its application to global health initiatives in rehabilitation. Phys Ther. 2009;89:1192-1202.

4. Pechak CM, Black JD. Exploring international clinical education in US-based programs: identifying common practices and modifying an existing conceptual model of international service-learning. Physiother Theory Pract. 2014;30:94-104.

5. American Physical Therapy Association. APTA Vision Statement for Physical Therapy. House of Delegates P06-00-24-35. American Physical Therapy Association Website. http://www.apta.org/AM/Template.cfm?Section=Policies_and_Bylaws\&Template=/CM/HT MLDisplay.cfm\&ContentID=25855. Accessed July 1, 2016.

6. Koplan JP, Bond TC, Merson MH, Reddy KS, Rodriguez MH, Sewankambo NK, Wasserheit JN. Towards a common definition of global health. Lancet. 2009;373(9679):1993-1995.

7. Commission on Accreditation of Physical Therapy Education. Evaluative criteria for accreditation of education programs for the preparation of physical therapists. Alexandria, VA: American Physical Therapy Association; 2014. 
8. Drain P, Primack A, Hunt DD, Fawzi, Holmes KK, Gardner P. Global health in medical education: a call for more training and opportunities. Acad Med. 2007;82:226-230.

9. McKinley DW, Williams SR, Norcini JJ, Anderson MB. International exchange programs and U.S. medical schools. Academic Medicine. 2008;83(10):S53-S57.

10. Pechak C, Thompson M. International service-learning and other international volunteer service opportunities in physical therapist education programs in the USA and Canada. $J$ Phys Ther Educ. 2009;23(1):71-79.

11. Pechak C, Thompson M. Going global in physical therapist education: international servicelearning in US-based programs. Physiother Res Int. 2011;16(4):225-236.

12. Frenk J, Chen L, Bhutta ZA, Cohen J, Crisp N, Evans T, Fineberg H, Garcia P, Ke Y, Kelley P, Kistnasamy B, Meleis A, Naylor D, Pablos-Mendez A, Reddy S, Scrimshaw S, Sepulveda J, Serwadda D, Zurayk H. Health professionals for a new century: transforming education to strengthen health systems in an interdependent world. Lancet. 2010;376:1923-1958.

13. Wittmann-Price RA, Anselmi KK, Espinal F. Creating opportunities for successful international student service-learning experiences. Holistic Nsg Pract. 2010;24(2):89-98.

14. Lattanzi JB, Pechak CM. Educating globally-minded physical therapist students: curriculum strategies to equip the next generation. J Phys Ther Educ. 2012;26:55-60.

15. Thompson MJ, Huntington MK, Hunt DD, Pinsky LE, Brodie JJ. Educational effects of international health electives on US and Canadian medical students and residents: a literature review. Acad Med. 2003;78:342-347. 
16. McBride AM, Mlyn E. International volunteer service: good intentions are not enough. The Chronicle of Higher Education website. http://www.chronicle.com/article/InternationalVolunteer/130459/. January 25, 2012. Accessed September 2, 2016.

17. Crump JA, Sugarman J. Ethical considerations for short-term experiences by trainees in global health. JAMA. 2008;300:1456-1458.

18. Landry MD, Nixon S, Raman SR, Taylor JS, Tepper J. Global health experiences (GHEs) in physical therapist education: balancing moral imperative with inherent moral hazard. $J$ Phys Ther Educ. 2012;26:24-28.

19. Pechak CM, Cleaver S. A call for a critical examination of ethics in global health initiatives in physical therapy education. Health Policy and Administration Resource. 2009;9:9-10.

20. Lattanzi JB, Pechak C. A conceptual framework for international service-learning course planning: promoting a foundation for ethical practice in the physical therapy and occupational therapy professions. J Allied Health. 2011;40(2):103-109.

21. Fischer K. Some health programs overseas let students do too much too soon. Chron High Educ. 2013; Nov 4.

22. Frederick B. International risk management. https://www.nols.edu/nolspro/pdf/wrmc_proceedings_06_international_risk_fedrick.pdf Accessed September 6, 2016.

23. Myles W, Mitchell L. Worth the risk: four approaches to safety in international learning. CBIE Research, Canadian Bureau for International Education, http://files.eric.ed.gov/fulltext/ED549875.pdf. Accessed September 6, 2016. 
International Learning Opportunities

24. Thompson MJ, Huntington MK, Hunt DD, Pinsky LE, Brodie JJ. Educational effects of international health electives on U.S. and Canadian medical students and residents: a literature review. Acad Med. 2003;78(3):342-347.

25. Driscoll A. Studying faculty and service-learning: directions for inquiry and development. Mich J Community Serv Learning. Special Issue: Strategic Directions for Service-Learning Research. 2000:35-41.

26. Hammond C. Integrating service and academic study: faculty motivation and satisfaction in Michigan higher education. Mich J Community Serv Learning. 1994;1(1):21-28.

27. O’Meara K, Niehaus E. Service-learning is... How faculty explain their practice. Mich J Community Serv Learning. 2009;16(1):17-32.

28. Fell DW, Kim K. Developing international collaborations in physical therapy academia: a case example emphasizing education and scholarship. J Phys Ther Educ. 2012;26:6-12.

29. Crump JA, Sugarman J. Working Group on Ethics Guidelines for Global Health Training (WEIGHT). Global health training: ethics and best practice guidelines for training experiences in global health. Am J Trop Med Hyg. 2010;83:1178-1182.

30. Pechak CM, Black JD. Proposed guidelines for international clinical education in US-based physical therapist education programs: results of a focus group and Delphi study. Phys Ther. 2014;94(4);523-533.

31. Petrosoniak A, McCarthy A, Varpio L. International health electives: thematic results of student and professional interviews. Med Educ. 2010;44(7):683-9.

32. Dell EM, Varpio L, Petrosoniak A, Gajaria A, McCarthy AE, The ethics and safety of medical student global health electives. Int J Med Educ. 2014;5:63-72. 
33. Resources for core education program workshop: health, safety, and risk management in education abroad. NAFSA: Association of International Educators website. http://www.nafsa.org/findresources/Default.aspx?id=8588. Accessed September 2, 2016.

34. SAFETI Clearinghouse: Safety Abroad First Education Travel Information. The Center for Global Education website. http://globaled.us/safeti/crisis_and_management/analyze_risk_and_capabilities.asp. Accessed September 2, 2016.

35. A resource guide for managing risk in service learning. The California State University Center for Community Engagement website. https://www.calstate.edu/cce/resource_center/documents/CCE_ResGuide_2011_webvs_Final .pdf. Accessed September 12, 2016.

36. Beyond the classroom. Experiential learning: managing risks, maximizing rewards. Gallagher Higher education Practice Group website. https://www.ajg.com/media/850665/Beyond-the-Classroom-Experiential-Learning.pdf. Accessed September 13, 2016.

37. Hoppes S, Bender D, Degrace BW. A service learning is a perfect fit for occupational and physical therapy education. J Allied Health. 2005;34(1):47-50.

38. Reicherter FA, Manual Williams B. Service learning in physical therapy: enhancing healthy lifestyles of older African American adults in Washington, DC. Creative Coll Teach J. 2005; 2(1):65-77.

39. Deardorff D. Identification and assessment of intercultural competence as a student outcome of internationalization. J Stud Internat Educ. 2006;10(3):241-266. 
International Learning Opportunities

40. Hesser G. Faculty assessment of student learning: outcomes attributed to service-learning and evidence of changes in faculty attitudes about experiential education. Mich J Community Serv Learning. 1995;2:33-42.

41. Beling J. Impact of service learning on physical therapist students' knowledge of attitudes toward older adults and on their critical thinking ability. J Phys Ther Educ. 2004;18(1):1321.

42. Tishman S, Jay E, Perkins DN. Teaching thinking dispositions: From transmission to enculturation. Theor Pract. 1993;32(3):147-153.

43. Lilley K, Barker M, Harris N. The global citizen conceptualized: accommodating ambiguity. J Stud Internat Educ. 1-16. doi: 10.1177/1028315316637354

44. Braskamp LA. Developing global citizens. J Coll Character. 2008;10(1):1-7.

45. Myers-Lipton SJ. Effect of service-learning on college students' attitudes toward international understanding. J Coll Student Dev. 1996;37(6):659-668.

46. Hayward LM, Charrette AL. Integrating cultural competence and core values: an international service-learning model. J Phys Ther Educ. 2012;26:78-89.

47. Lee ACW, Litwin B, Cheng MS, Harada ND. Social responsibility and cultural competence among physical therapists with international experience. J Phys Ther Educ. 2012;26:66-73.

48. Ekelman B, Bello-Haas VD, Bazyk J, Bazyk S. Developing cultural competence in occupational therapy and physical therapy education: a field immersion approach. $J$ Allied Health. 2003;32:131. 
International Learning Opportunities

49. Peiying N, Goddard T, Gribble N, Pickard C. International placements increase the cultural sensitivity and competency of professional health students: a quantitative and qualitative study. J Phys Ther Educ. 2012;26:61-68.

50. Ganley KJ, Mueller K. Clinically relevant outcomes of immersion in a community service based experience for physical therapy students. Pediatr Phys Ther. 2006;18(1):90-101.

51. Petersen CM, Harrison L, Wohlers C. Evaluation of an international service-learning/clinical education experience utilizing an existing conceptual model. J Phys Ther Educ. 2015;29(1):34-42.

52. Sawyer K, Lopopolo R. Perceived impact on physical therapist students of an international pro bono clinical education experience in a developing country. J Phys Ther Educ. 2004;18:40-47.

53. Reynolds PJ. How service-learning experiences benefit physical therapist students' professional development: a grounded theory study. J Phys Ther Educ. 2005;19(1):41-51.

54. Ash SL, Clayton PH, Atkinson MP. Integrating reflection and assessment to capture and improve student learning. Mich J Community Serv Learning. 2005;11(2):49-60.

55. Hatcher JA, Bringle RG, Muthiah R. Designing effective reflection: what matters to servicelearning? Mich J Community Serv Learning. 2004;11(1):38-46.

56. Portney LG, Watkins MP. Foundations of clinical research. Upper Saddle River, NJ: Prentice Hall; 2009.

57. SPSS [computer program]. Version 24. Armonk, NY:IBM;2016.

58. Roberts B. Good guidance on the ground: mentoring international service learning programs. Metropolitan Universities: An International Forum, 2000;11(1):45-52. 
International Learning Opportunities

59. Lupton RD. Toxic charity: how churches and charities hurt those they help. Harper One, USA, 2011.

60. Lowrey D, May DL, Duchane KA, Coulter-Kern R, Bryant D, Morris PV, Pomery JG, Bellner M. A logic model of service-learning: tensions and issues for further consideration. Mich J Community Serv Learning. 2006;12(2):47-60.

61. Seaborg E. Presentation: International education best practices. United Educators Insurance Company, Chevy Chase, Maryland. May 7, 2013. Used with permission.

62. Kubolk PA, Mitchell EM, Glick GF, Greiner D. International experiences in nursing education: a review of the literature. Int J Nurs Educ Scholarsh. 2012;9:1-21.

63. Curtin AJ, Martins DC, Schwartz-Barcott D, DiMaria LA, Ogando BM. Exploring the use of critical reflective inquiry with nursing students participating in an international servicelearning experience. J Nurs Educ. 2015;54(9):S95-8.

64. Long T. Influence of international service learning on nursing students' self efficacy towards cultural competence. J Cult Divers. 2016;23(1):28-33.

65. Mandich MB, Erickson M, Nardella B. Development of an international clinical education extracurricular experience through a collaborative partnership: a case study. Phys Ther, early online September 8, 2016.

66. Kohlbry P, Daugherty J. International service-learning: an opportunity to engage in cultural competence. J Prof Nurs. 2015;31(3):242-6.

67. Krishnan LA, Richards KA, Simpson JM. Outcomes of an international audiology servicelearning study-abroad program. Am J Audiol. 2016;25(1):1-13. 
International Learning Opportunities

68. De Los Santos M, McFarlin CD, Martin L. Interprofessional education and service learning: a model for the future of health professions education. J Interprof Care. 2014;28(4):374-5.

69. Foster J, Pullen S. International service learning in the Dominican Republic: an asynchronous pilot in interprofessional education. J Interprof Care. 2016;30(2):257-8. 